Annals of Tropical Research 32[1]:55-71(2010)

(c) VSU, Leyte, Philippines

\title{
Cassava grates processing wastes as source of electrical energy
}

\author{
Mark Anthony R. Atanacio', Daniel Leslie S. Tan ${ }^{2}$ and Felix J. Amestoso ${ }^{3}$ \\ ${ }^{1}$ Department of Agricultural Engineering, College of Engineering and \\ Agri-Industries, Visayas State University, Baybay City, Leyte, 6521-A Philippines; \\ ${ }^{2}$ Philippine Root Crops Research and Training Center, \\ Visayas State University, Baybay City, Leyte, 6521-A Philippines; \\ ${ }^{3}$ Department of Food Science and Technology, College of Agriculture, \\ Visayas State University, Baybay City, Leyte, 6521-A Philippines
}

\begin{abstract}
The study aimed to generate electricity from cassava (Manihot esculenta) extract using an improvised microbial fuel cell (MFC). In the development of the MFC, screening experiment using 8-run Plackett-Burman (PB) technique and optimization procedure following response surface methodology (RSM) were employed. More cassava extract concentration significantly increased the generated voltage and the significance exhibited by salt ratio was inversely proportional to the voltage generated. One of the treatments in the $3 \times 3$ factorial experiment reached the maximum voltage of $546 \mathrm{mV}$.

Response surface regression analysis of all the response studied revealed that linear, quadratic, and cross product regression of cassava extract concentration and salt ratio in the salt bridge significantly affected the voltage which further developed a regression model represented as $\triangle E=106+1318 x-4829 y-850 x^{2}-787 x y+18032 y^{2}$.

The canonical analysis of the voltage showed minimum response at the stationary point inside the factor level space equal to $211 \mathrm{mV}$. Salt ratio level lower than $15 \%$ and cassava extract concentration not less than $60 \%$ generated a higher voltage value. Ttest showed no significant difference of voltage between days, and between the predicted mean and the observed mean, which had \% accuracy of 92.54 , and $93.28 \%$."
\end{abstract}

Key words: Cassava grates processing waste, microbial fuel cell, electricity, response surface methodology

Correspondence: D. L. S. Tan. Address: Philippine Root Crops Research and Training Center, Visayas State University, Baybay City, Leyte, 6521-A, Philippines E-mail: dlstan@yahoo.com DOI: $10.32945 /$ atr3214.2010 


\section{INTRODUCTION}

Issues related to oil and gas reserves are very hot not only to the people in the Philippines but also in other countries. This is because the world's fossil fuel is depleting. Therefore it is a must to find alternative forms of energy as early as now to be ready for the future. Besides, there are still a lot of alternative fuels undiscovered and the existing ones can still be improved and modified.

Currently, research on harnessing fuels is on its fast development, especially those that are environment-friendly and do not compete with the production of food such as planting Jatropha curcas for biodiesel production instead of planting cassava as source of food. We have now recent remedies for these; the use of wastewaters and crop residues like the cassava liquid residues, which are completely unusable and toxic, but can be used as a source of electrical energy through microbiological techniques. Assurance of clean form of energy without competition from food production perhaps is attainable.

Cassava extract is produced during processing of cassava flour and grates. Squeezing or using a mechanical spinner usually extracts cassava liquid wastes. Even nowadays, the benefits from cassava liquid wastes in the Philippines are still to be harnessed with potential to produce biogas. C-BETech (2007) stated that the main constraint is a high cyanide load in the extract that will obstruct the growing of methane bacteria so methanol genesis fermentation process does not run. Based on the above condition, a pre-treatment component is needed to reduce cyanide load before methanol genesis fermentation process occurs.

Microbial fuel cells are important in the advancement of alternative fuels. Electricity can be produced using the degradation of organic matter by microorganisms. Rabaey and Verstraete (2005) reported that microbial fuel cells (MFCs) have operational and functional advantages over the technologies currently used for generating energy from organic matter. First, the direct conversion of substrate energy to electricity enables high conversion efficiency. Second, MFCs operate efficiently at ambient, even at low temperatures distinguishing them from all current bio-energy processes. Third, an MFC does not require gas treatment because the off-gases of MFCs are rich in carbon dioxide and normally have no useful energy content. Fourth, MFCs do not need energy input for aeration provided the cathode is passively aerated. 
Fifth, MFCs have potential for widespread application in locations lacking electrical infrastructures and also to expand the diversity of fuels used to satisfy energy requirements.

The used cassava liquid residue in the microbial fuel cell no longer requires pre-treatment of the cyanide content because anaerobic microorganisms can grow on substrates containing cyanide (Sangyoka et al., 2007). Moreover, it has many practical uses to help a growing economy in the near future. Microbial fuel cell technology could contribute to improve environmental protection and in food production sector in most developing countries. Thus, this study was conducted to determine the voltage generated by the cassava extract using an improvised microbial fuel cell. The results of this study are very useful for the ongoing improvement and development of the microbial fuel cell.

\section{MATERIALS AND METHODS}

\section{Procurement of raw material}

Cassava liquid extract from fresh cassava roots (Lakan variety) were obtained from PhilRootcrops, Visayas State University, Philippine. During

processing of cassava grates and flour, the liquid product was extracted mainly from the roots (not including the wash water) by mechanical spinning. This extract is composed mostly of water and starch particles. The used electrodes from dry cells as well as the plastic containers were collected while the epoxy, solid wire, and transparent tubes were purchased from CLU Commercial and Brodeth Marketing, Baybay City, Philippines. The seawater was obtained from the shores of Camotes Sea.

\section{Variable screening}

Screening was carried out to establish a workable generation of voltage using seven variables that were evaluated i.e. cassava extract concentration (\% cassava extracts with and without the addition of tap water), electrode size, diameter of electrode, length of electrode, salt ratio at the salt bridge, volume of extracts, and the levels of sugar added. 


\section{Assembling and running the improvised microbial fuel cell}

The improvised MFC was the device used for the conversion of cassava extract to electrical energy by the catalytic reaction of the microorganisms present. The MFC was composed of two chambers: the anode chamber and the cathode chamber. Both chambers were using identical 1.5-liter soft drink containers. A so-called ion-exchange membrane otherwise known as salt bridge was connected between the two chambers (Figure 1). The salt bridge was connected between the two plastic containers. Each of these containers was holed according to the sizes of the supporter tube where the salt bridges were fitted. The supporter tube was sealed well to prevent leakage of extract and seawater. After the cassava extract was added to the anode chamber, the electrode was hurriedly put so that minimal air was captured, then was sealed with an epoxy. On the other hand, seawater was poured on the cathode chamber which was just opened to let air circulate.

\section{Monitoring factor}

The temperature as the monitoring factor was taken into account for it affects the fermentation process at the anode chamber. This factor was not treated as parameter of this study, but was still determined to keep track of the whole process. Aglass type thermometer was used to measure temperature along with the voltage measurement.

\section{Experimental designs}

The 8-run Plackett-Burman (PB) design was employed in the screening experiment. Table 2 shows the $\mathrm{PB}$ design including the range of values for the different variables used and designated as (-) for low and (+) for high. The two most highly significant variables were then subjected to $3 \times 3$ factorial experiment.

\section{Gathered data}

The voltages $(\mathrm{mV})$ from the variable screening, $3 \times 3$ factorial experiment, and from the verification of regression model was determined using a digital multi-meter (Figure 2). The voltage of each set-up was measured three times a day ( 5 a.m., 1 p.m., and 9 p.m.). The generated voltage per day was the average of the three measurements. 


\section{Analysis of data}

The results from the PB screening design were analyzed to determine significant variables that have significant effect. The data from the different treatments from the $3 \times 3$ factorial experiment were analyzed using the statistical computer software SAS (1985) as cited by Oroc (2006) following the response surface regression analysis to determine the effects of independent variables on the voltage generated by the improvised MFC. Significant difference of voltage in every $10^{\text {th }}$ day and verification experiment employed the T-test.

\section{Verifying the result}

After analyzing the data from the factorial experiment, another assessment was conducted to verify whether the 2 variables would match with the result using levels fitted into the generated regression line models. The obtained results were compared with the result for the $3 \times 3$ factorial experiment.

\section{RESULTS AND DISCUSSION}

\section{Working mechanism of the laboratory microbial fuel cell}

The MFC used anaerobic microorganisms as a catalyst to convert wastewater into ions. These bacteria convert a huge variety of organic compounds into $\mathrm{CO}_{2}$, water and energy (Thauer et al., 1977). They used the produced energy to grow, however, by using MFC, a part of this energy can be harvested in the form of electricity.

The extract is fed into the anode, and oxygen (or air) enters the cell through the cathode. The anode is a sealed chamber, thus forcing microorganisms to use anaerobic respiration (Benneto, 1990) making the hydrogen atoms split into protons and electrons. Due to the ability of bacteria to transfer electrons to graphite electrodes, these electrons through external loads can be generated in the form of electricity before they return to the cathode as revealed by Jardon (2005). The electron transfer via wires to the cathode and the potential difference between the anode and the cathode, 
Table 1. Mean voltage of the 8-run Plackett-Burman experiment as affected by the range of values of the variables

\begin{tabular}{|c|c|c|c|c|c|c|c|c|}
\hline \multirow[t]{2}{*}{ Run No. } & \multicolumn{7}{|c|}{ Variables } & \multirow{2}{*}{$\begin{array}{l}\text { Mean voltage } \\
\text { Generated } \\
(\mathrm{mV})\end{array}$} \\
\hline & A & B & $\mathrm{C}$ & $\mathrm{D}$ & E & $\mathrm{F}$ & $\mathrm{G}$ & \\
\hline 1 & $2 a$ & $70 \mathrm{a}$ & $1.30 \mathrm{a}$ & $10 \mathrm{~b}$ & $10 \mathrm{a}$ & $500 \mathrm{~b}$ & $0 \mathrm{~b}$ & 53 \\
\hline 2 & $2 a$ & $70 \mathrm{a}$ & $0.80 \mathrm{~b}$ & $20 \mathrm{a}$ & $5 b$ & $500 \mathrm{~b}$ & $3 a$ & 245 \\
\hline 3 & $2 a$ & $30 \mathrm{~b}$ & $1.30 \mathrm{a}$ & $10 \mathrm{~b}$ & $5 b$ & $1000 \mathrm{a}$ & $3 a$ & 48 \\
\hline 4 & $1 \mathrm{~b}$ & $70 \mathrm{a}$ & $0.80 \mathrm{~b}$ & $10 \mathrm{~b}$ & $10 \mathrm{a}$ & $1000 \mathrm{a}$ & $3 a$ & 103 \\
\hline 5 & $2 a$ & $30 \mathrm{~b}$ & $0.80 \mathrm{~b}$ & $20 \mathrm{a}$ & $10 \mathrm{a}$ & $1000 \mathrm{a}$ & $0 \mathrm{~b}$ & 28 \\
\hline 6 & $1 \mathrm{~b}$ & $30 \mathrm{~b}$ & $1.30 \mathrm{a}$ & $20 \mathrm{a}$ & $10 \mathrm{a}$ & $500 \mathrm{~b}$ & $3 a$ & 87 \\
\hline 7 & $1 \mathrm{~b}$ & $70 \mathrm{a}$ & $1.30 \mathrm{a}$ & $20 \mathrm{a}$ & $5 b$ & $1000 \mathrm{a}$ & $0 \mathrm{~b}$ & 178 \\
\hline 8 & $1 b$ & $30 \mathrm{~b}$ & $0.80 \mathrm{~b}$ & $10 \mathrm{~b}$ & $5 b$ & $500 \mathrm{~b}$ & $0 \mathrm{~b}$ & 63 \\
\hline
\end{tabular}

Note: A - size of electrode (2- from size D dry cell and 1- from size AA dry cell); B - concentration of cassava extract (\%); C - diameter of salt bridge (cm); D - salt bridge length $(\mathrm{cm}) ; \mathrm{E}$ - salt ratio in the salt bridge (\%); F - volume of the cassava extract $(\mathrm{mL}) ; \mathrm{G}$ - amount of sugar added $(\mathrm{g})$; a- high range of value; $b$ - low range of value; $\%\left({ }^{\mathrm{w}} / \mathrm{v}\right)$ or $(\mathrm{v} / \mathrm{v})$ of water used

Table 2. Result for the different variables used in Plackett-Burman experiment

\begin{tabular}{lllll}
\hline & Effect & Std. Error & $\mathrm{T}(40)$ & $\mathrm{P}$ \\
\hline Mean/ Intersection & 0.1061 & 0.0104 & 10.1622 & 0.0000 \\
Size of Electrode & -0.0030 & 0.0209 & $-0.1417 \mathrm{a}$ & 0.8881 \\
Extract Concentration & 0.0767 & 0.0209 & $3.6734 \mathrm{~b} 0$ & .0007 \\
Diameter of salt bridge & -0.0072 & 0.0209 & $-0.3452 \mathrm{~ns}$ & 0.7318 \\
Length of salt bridge & 0.0565 & 0.0209 & $2.7077 \mathrm{c}$ & 0.0099 \\
Salt ratio in salt bridge & -0.0767 & 0.0209 & $-3.6734 \mathrm{~b}$ & 0.0007 \\
Volume of extract & -0.0117 & 0.0209 & $-0.5607 \mathrm{a}$ & 0.5781 \\
Amount of sugar added & 0.0512 & 0.0209 & $2.4523 \mathrm{~d}$ & 0.0187 \\
\hline
\end{tabular}

Note: a- not significant; $\mathrm{b}$ - significant at $\mathrm{P}<0.001$; c- significant at $\mathrm{P}<0.01$; d- significant at $\mathrm{P}<0.05$; the sign and magnitude of the effect indicates the manner and degree of the main effects of the variable 


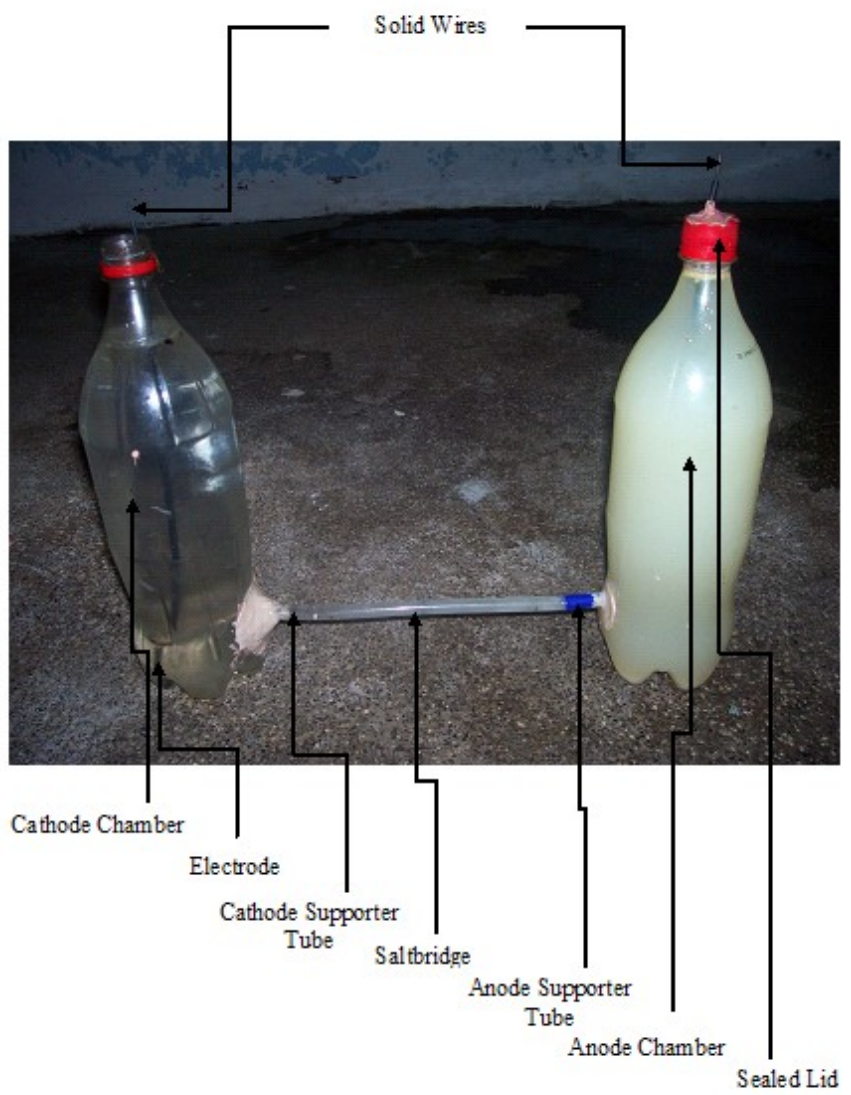

Figure 1. The improvised microbial fuel cell used in the experiment 


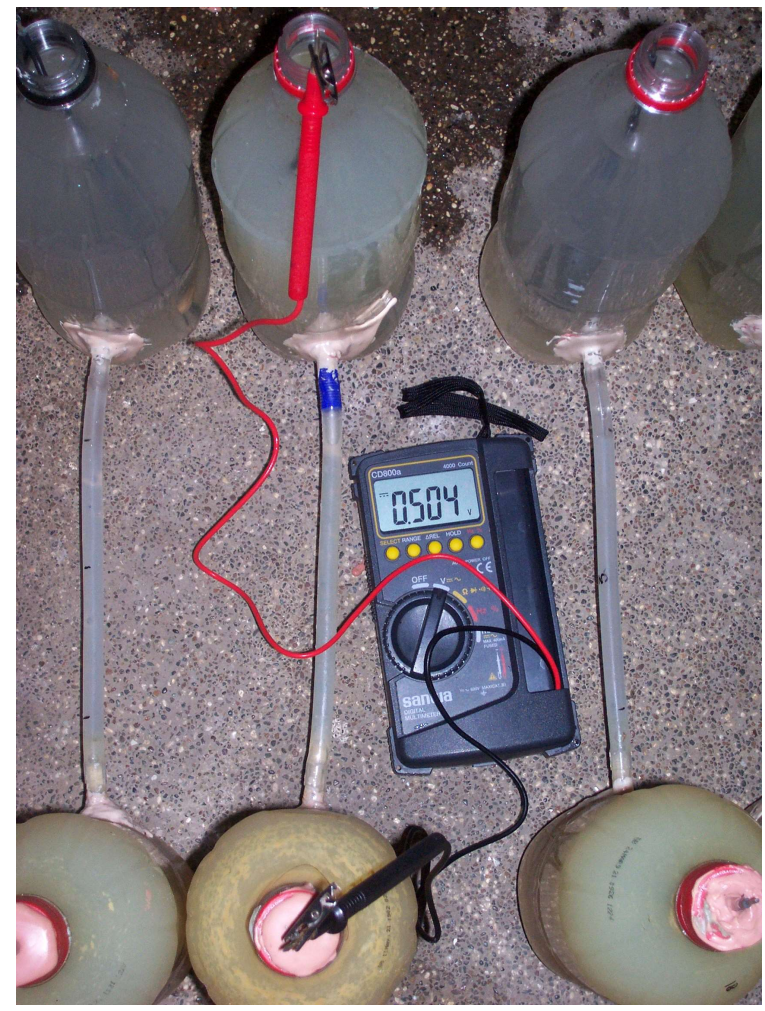

Figure 2. Measuring the generated voltage from the MFC 
together with the flow of electrons results in the generation of electrical power (Figure 3). The protons flow through the salt bridge to the cathode forming water to close the circuit.

Voltage generated by the improvised $M F C$

Screening of variables

The mean voltage of the 8-run PB experiment (Table 1) was analyzed to determine the effect of variables on the generated voltage. The effect of the estimates for the analysis of different variables revealed cassava extract concentration, length of the salt bridge, and the amount of sugar added had positive significant effects. Whereas, electrode size, diameter of the salt bridge, ratio of salt in the salt bridge, and volume of the cassava extract showed negative effects. However, only the salt ratio in the salt bridge was significant. The range of values of the significant variables considerably influenced the voltage according to their level of significance (Table 2). Runs with $67 \%$ cassava concentration have high voltage, an indication that the voltage will increase as the concentration is increased and perhaps this is the reason why cassava concentration reveals a very large positive effect. The salt ratio in the salt bridge did have the same effect as large as the cassava concentration though negative, maybe because electrons transferred were minimal with high salt content. It revealed that addition of sugar to the anode and longer salt bridges have high voltage. This might be due to the salt inside long salt bridges that does not easily run-out. Cassava extract might lack enough carbon constituents to support long term electrical generation(Frew and Christy, 2006) attesting why addition of sugar significantly affected the electrical voltage generated.

\section{Factorial experiment}

The result of the PB variable screening called for further experimental evaluation of the two selected significant variables, cassava extract concentration and salt ratio in the salt bridge. Levels of cassava wastewater were $100 \%$, $67 \%$, and $33 \%(\mathrm{~V} / \mathrm{V})$ while the salt ratio in the salt bridge was $15 \%, 10 \%$, 


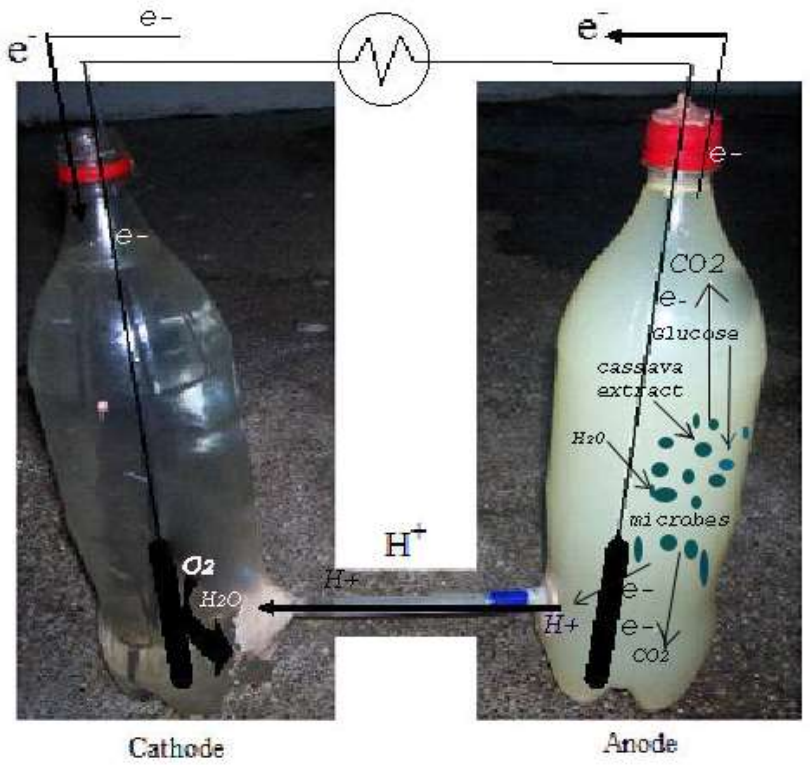

Figure 3. Flow of charges in a Laboratory MFC 
Table 3. Voltage $(\mathrm{mV})$ as affected by the levels of starch and water (concentration), and level of salt in the salt bridge

\begin{tabular}{lllll}
\hline \multirow{2}{*}{$\begin{array}{l}\text { Extract } \\
\text { Concentration } \\
(\%)\end{array}$} & $\begin{array}{l}\text { Approximate } \\
\text { Water-Starch } \\
\text { Ratio (\%) }\end{array}$ & \multicolumn{3}{c}{ Salt Ratio (\%) } \\
\cline { 3 - 5 } & $89-90: 10-11$ & 15 & 10 & 5 \\
\hline 100 & $93-94: 6-7$ & 100 & 270 & 300 \\
67 & $95-96: 4-5$ & 214 & 243 & 390 \\
33 & 125 & 52 & 273 \\
\hline
\end{tabular}

Overall Response Mean $=218 \mathrm{mV}$

Table 4. Summary of voltage in all treatments subjected to $3 \times 3$ factorial experiment

\begin{tabular}{lccc}
\hline Treatment & \multicolumn{3}{c}{ Voltage $(\mathrm{mV})$} \\
\cline { 2 - 4 } & $\mathrm{R}^{\mathrm{a}}$ & $\mathrm{R}^{\mathrm{a}}$ & Overall Mean \\
\hline $\mathrm{T} 1$ & 157 & 42 & 100 \\
$\mathrm{~T} 2$ & 200 & 259 & 270 \\
$\mathrm{~T} 3$ & 231 & 369 & 300 \\
T4 & 256 & 172 & 214 \\
T5 & 232 & 255 & 243 \\
T6 & 409 & 371 & 390 \\
T7 & 149 & 101 & 125 \\
T8 & 53 & 52 & 52 \\
T9 & 304 & 241 & 273 \\
\hline
\end{tabular}

Note: average of the 20-day recording of data

and $5 \%(\mathrm{~W} / \mathrm{V})$ and the combination resulted to nine treatments (Figure 4).

Table 3 shows the means of voltage, as affected by the levels of salt in the salt bridge and cassava extract concentration, ranged from 52 to $390 \mathrm{mV}$. Within 20 days of measurement, Treatment 6 reached to a maximum voltage $(546 \mathrm{mV})$ with an average voltage of $409 \mathrm{mV}$ in one of the replicates (Table 4) with lowest change of voltage (about $4 \mathrm{mV}$ ) in every 10 days (Table 5). During these days, the temperature ranged from $24^{\circ}$ to $25^{\circ} \mathrm{C}$. It can be observed in Figure 5 that the electricity can still be utilized for longer period of time. T-test revealed that there is no significant difference from the change of voltage during the first 10 days of measurement to the next 10 days (Table 5). This means that within this period of time, generated voltage is still on its peak yield. 
Table 5. T-test of the mean voltage $(\mathrm{mV})$ for all treatments measured every 10 days

\begin{tabular}{lllll}
\hline Treatment & $\begin{array}{l}\text { Mean at } \\
1-10 \text { days } \\
\text { (D1) }\end{array}$ & $\begin{array}{l}\text { Mean at } \\
11-20 \text { days } \\
\text { (D2) }\end{array}$ & /D1-D2/ & tcomputed \\
\hline T1 & 110 & 90 & 20 & \\
T2 & 287 & 253 & 34 & $0.055 \mathrm{a}$ \\
T3 & 285 & 315 & 30 & $0.095 \mathrm{a}$ \\
T4 & 180 & 248 & 68 & $0.086 \mathrm{a}$ \\
T5 & 257 & 229 & 28 & $0.189 \mathrm{a}$ \\
T6 & 388 & 392 & 4 & $0.078 \mathrm{a}$ \\
T7 & 127 & 123 & 4 & $0.013 \mathrm{a}$ \\
T8 & 57 & 47 & 10 & $0.011 \mathrm{a}$ \\
T9 & 258 & 287 & 29 & $0.027 \mathrm{a}$ \\
\hline
\end{tabular}

Note: a- not significant; $\mathrm{SD}=1.134 ; \mathrm{n}=10 ; \mathrm{t}(5 \%, 9)=2.262 ; \mathrm{t}(1 \%, 9)=3.250$ $\mathrm{T} 1(100 \%$ cassava extract and $15 \%$ salt in the salt bridge); $2(100 \%$ cassava extract and $15 \%$ salt in the salt bridge); T3(100\% cassava extract and $15 \%$ salt in the salt bridge); $\mathrm{T} 4(100 \%$ cassava extract and $15 \%$ salt in the salt bridge); 5 (100\% cassava extract and $15 \%$ salt in the salt bridge); T6(100\% cassava extract and $15 \%$ salt in the salt bridge); $\mathrm{T} 7(100 \%$ cassava extract and $15 \%$ salt in the salt bridge); $\mathrm{T} 8(100 \%$ cassava extract and $15 \%$ salt in the salt bridge); T9(100\% cassava extract and $15 \%$ salt in the salt bridge $)$

\section{The Regression model}

The regression model that from the $3 \times 3$ factorial experiment was generated by the SAS software following surface regression analysis. This is shown in the equation, $\triangle E=106+1318 x-4829 y-850 x^{2}-787 x y+18032 y^{2}$, were $\triangle \mathrm{E}$ is the voltage $(\mathrm{mV})$ value while $\mathrm{x}$ are levels of cassava extract $(\%)$ and $y$ are levels of cassava extract (\%). The model indicated that the different levels of variables significantly affected the voltage in linear, quadratic and crossproduct terms (Tables 6a and Table 6b). All parameters analyzed significantly affected the potential difference which means the observed variation in voltage was brought about by the different levels of both the salt ratio in the salt bridge and cassava extract concentration and/or any combination or interaction of these variables.

As what has been expected from the result of variable screening that voltage will increase as the concentration will go higher, however, it revealed that $100 \%$ concentrations did not yield the maximum voltage. This surely 
Table 6a. ANOVA for voltage of the improvised MFC

\begin{tabular}{|c|c|c|c|c|c|}
\hline Regression & $\begin{array}{l}\text { Degrees } \\
\text { of Freedom }\end{array}$ & $\begin{array}{l}\text { Sum } \\
\text { of Squares }\end{array}$ & R-Square & $\begin{array}{l}\text { F- } \\
\text { Ratio }\end{array}$ & Prob $>F$ \\
\hline Linear & 2 & 0.4333 & 2.160544 & $200.4^{\mathrm{a}}$ & 0.0000 \\
\hline Quadratic & 2 & 0.1784 & 0.889658 & $82.533^{\mathrm{a}}$ & 0.0000 \\
\hline Cross product & 1 & 0.0056 & 0.027789 & $5.156^{\mathrm{b}}$ & 0.0238 \\
\hline Total Regress & 5 & 0.6173 & 3.077992 & $114.2^{\mathrm{a}}$ & 0.0000 \\
\hline
\end{tabular}

Note: a- Significant at $\mathrm{P}<0.001$; b- Significant at $\mathrm{P}<0.05$; $\operatorname{Root} \mathrm{MSE}=0.073415$;

R-Square $=0.6173$; Coef. Of Variation $=33.6015$

Table 6b. Parameter estimates of response surface of voltage of the improvised MFC

\begin{tabular}{llllll}
\hline Parameter & $\begin{array}{l}\text { Degrees } \\
\text { of Freedom }\end{array}$ & $\begin{array}{l}\text { Parameter } \\
\text { Estimates }\end{array}$ & $\begin{array}{l}\text { Standard } \\
\text { Error }\end{array}$ & $\begin{array}{l}\text { T for HO: } \\
\text { Parameter }=0\end{array}$ & Prob $>/ \mathrm{T} /$ \\
\hline INTERCEPT & 1 & 0.106070 & 0.046840 & $2.265^{\mathrm{b}}$ & 0.0241 \\
SALT & 1 & 0.013179 & 0.001041 & $12.656^{\mathrm{a}}$ & 0.0000 \\
CEC & 1 & -0.048289 & 0.007025 & $-6.874^{\mathrm{a}}$ & 0.0000 \\
SALT*SALT & 1 & -0.000084971 & 0.000007316 & $-11.615^{\mathrm{a}}$ & 0.0000 \\
CEC*SALT & 1 & -0.000078677 & 0.0000034649 & $-2.271^{\mathrm{b}}$ & 0.0238 \\
CEC*EC & 1 & 0.001803 & 0.000328 & $5.492^{\mathrm{a}}$ & 0.0000 \\
\hline
\end{tabular}

Note: a- Significant at $\mathrm{P}<0.001$; $\mathrm{b}$ - Significant at $\mathrm{P}<0.05$; CEC-Cassava Extract Concentration

reflects in the natural habitat that substrate concentrations may be low so that "active" accumulation within the cell should be required for an effective catabolism (Thauer et.al, 1977). Furthermore, the water-glucose ratio where the microorganisms are active was attained at $67 \%$ cassava extract concentration where the approximate amount of water and starch ranged from 93 to $94 \%$ and from 6 to $7 \%$, respectively (Table 5). Therefore $100 \%$ extract concentration have insufficient amount of water to optimize the concentration for efficient activation of microorganisms. It can be said that microbes' optimum effective ability to transfer their electrons to the electrode is at $80 \%$ concentration using the regression model.

The predicted minimum voltage value was $211 \mathrm{mV}$. It occurs at the intersection of the critical values of $14.93 \%$ salt ratio in the salt bridge and $70.64 \%$ cassava extract concentration just located inside the factor level space (Figure 6). The figure shows a saddle response surface which indicates that at 


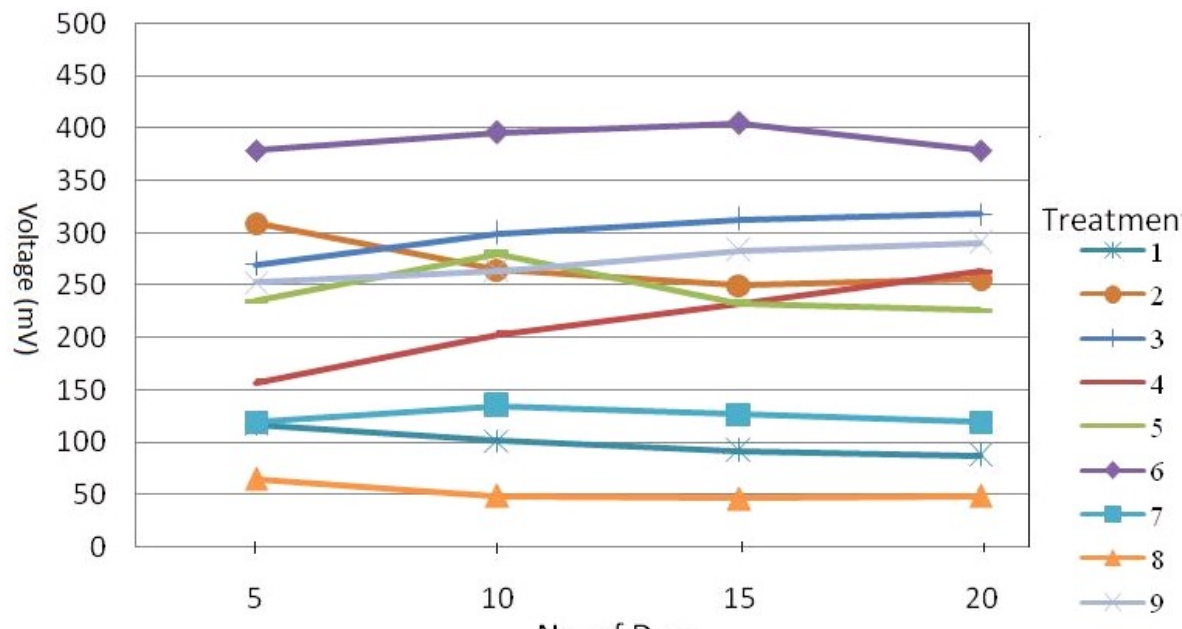

No. of Days

T1 ( $100 \%$ extract concentration; $15 \%$ salt ratio) T6 ( $67 \%$ extract concentration; $5 \%$ salt ratio)

T2 (100\% extract concentration; $10 \%$ salt ratio) T7 (33\% extract concentration; $15 \%$ salt ratio)

T3 (100\% extract concentration; $5 \%$ salt ratio) T8 (33\% extract concentration; $10 \%$ salt ratio)

T4 (67\% extract concentration; $15 \%$ salt ratio) T9 ( $33 \%$ extract concentration; $5 \%$ salt ratio)

T5 (67\% extract concentration; $10 \%$ salt ratio)

Figure 5. Plot of mean voltage value of all treatments at every 5 days of measurement

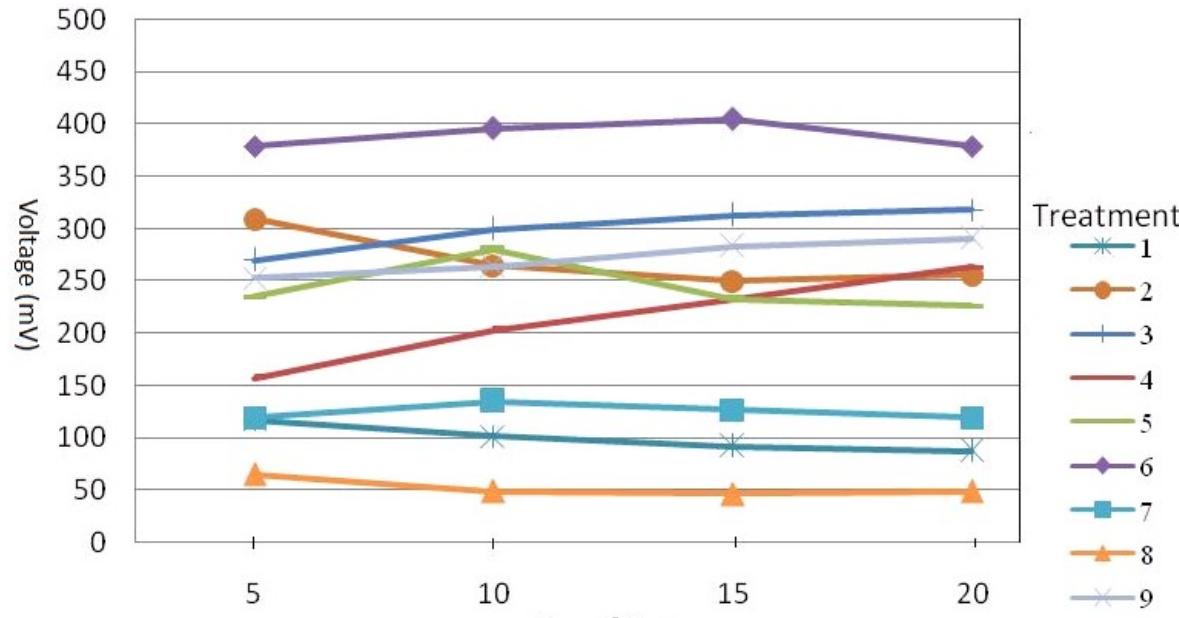

No. of Days

T1 (100\% extract concentration; $15 \%$ salt ratio) T6 ( $67 \%$ extract concentration; $5 \%$ salt ratio)

T2 (100\% extract concentration; $10 \%$ salt ratio) T7 ( $33 \%$ extract concentration; $15 \%$ salt ratio)

T3 ( $100 \%$ extract concentration; $5 \%$ salt ratio) T8 (33\% extract concentration; $10 \%$ salt ratio)

T4 (67\% extract concentration; $15 \%$ salt ratio) T9 ( $33 \%$ extract concentration; $5 \%$ salt ratio)

T5 (67\% extract concentration; $10 \%$ salt ratio)

Figure 6. Contour plot of the generated voltage $(\mathrm{mV})$ 
Table 7. Result of the t-test for verification of voltage $(\mathrm{mV})$ or potential difference model

\begin{tabular}{llcc}
\hline Treatment & Predicted Mean (Pi) & Observed Mean (Yi) & $\mathrm{t}_{\text {comp }}$ \\
\hline $\mathrm{Ta}$ & 388 & 417 & $0.099667854^{\mathrm{a}}$ \\
$\mathrm{Tb}$ & 211 & 225 & $0.04875344^{\mathrm{a}}$ \\
& & & \\
\hline
\end{tabular}

Note: $\mathrm{Ta}(70 \%$ extract concentration; $5 \%$ salt ratio in the salt bridge); $\mathrm{Tb}(70 \%$ extract concentration; $15 \%$ salt ratio in the salt bridge); a- not significant $; n=14 ; \mathrm{SD}=1.087115$; $\mathrm{t}(5 \%, 13)=1.771 ; \mathrm{t}(1 \%, 13)=2.650$

Table 8. Percent accuracy of the potential difference model

\begin{tabular}{llll}
\hline Treatment & /Pi-Yi/ & \% error & \% accuracy \\
\hline $\mathrm{Ta}$ & 29 & 7.460 & 92.54 \\
$\mathrm{~Tb}$ & 14 & 6.718 & 93.28 \\
\hline
\end{tabular}

Note: $\mathrm{Ta}(70 \%$ extract concentration; $5 \%$ salt ratio in the salt bridge); $\mathrm{Tb}(70 \%$ extract concentration; $15 \%$ salt ratio in the salt bridge

a given salt ratio in the salt bridge, voltage increases with the increase of cassava extract concentration level. For a given cassava extract concentration, voltage value increases with the decrease in salt ratio in the salt bridge. The effect of these variables explains enough their highly significant linear, quadratic and correspondent effect revealed by analysis (Tables 6a and 6b).

\section{Verification of the potential difference model}

Verification process employing t-test was carried out to determine if the observed mean were different from the predicted means obtained from the regression model. The result revealed no significant difference between the observed mean value and the predicted mean value of both new treatment $\mathrm{Ta}$ and $\mathrm{Tb}$ in the generated voltage (Table 7). This implies that the regression model of the response surface can predict voltage value of the improvised MFC by plugging-in values at anywhere in factor level space with \% accuracy of 92.54 to $93.28 \%$ (Table 8 ). 


\section{Test for the presence of electricity}

The presence of electricity was tested by connecting the individual MFC in series and was fitted to a calculator. Electricity was observed by the use of the calculator but was not tested for longer duration of operation.

\section{CONCLUSION}

The following conclusions could be drawn from the conducted study: PB screening experiment revealed that it is possible to produce voltage from a container less than a 1.5-liter; response surface regression analysis proved that the cassava extract concentration and salt ratio in the salt bridge indeed affected significantly the voltage generation; the regression model derived is a useful tool in predicting the voltage of specific levels of cassava extract and salt ratio in the salt bridge as needed in designing an MFC.

\section{RECOMMENDATIONS}

From the results of this study, there is a need for further investigation in a number of areas of concern: other variables like smaller containers, surface area and number of electrodes, type and design of salt bridge, type of wastewater, concentration of salt in the cathode chamber, and isolation and identification of bacteria shall be included in the design process; test the duration of the current when applied to a device; apply conductive epoxy to the electrode connections.

\section{LITERATURE CITED}

BENNETTO, H. P. 1990. Electricity generation by micro-organisms biotechnology education, 1 (4), pp. 163-168. Available from: http://en.wikipedia.org/wiki/ Microbial_fuel_cell, visited November 27, 2008.

C-BETECH. 2007. Available from: http://www.cbtech-lptp.org/modules/news/article.php, visited November 24, 2008. 
FREW, B. and A.D. CHRISTY. 2006. Use of landfill leachate to generate electricity in microbial fuel cells. American Society of Agricultural and Biological Engineers, St. Joseph, Michigan. Also Available from: http://asae.frymulti.com/ abstract.asp?aid=21030\&t=2, visited November 28, 2008.

JARDON, M. 2005. Microbial Fuel cells from Rhodopherax ferrireducens. The Science Creative Quarterly.

OROC, C.S. 2006. Variable screening, quality evaluation, and process optimization of tiessa (Pouteria campechiana Baehni) nectar. Unpublished Food Science and Technology Student Thesis, Visayas State University, Visca Baybay city, Leyte. $114 \mathrm{pp}$.

RABAEY, K. and W. VERSTRAETE. 2005.Microbial fuel cell: novel biotechnology for energy generation. Laboratory of Microbial Ecology and Technology. Ghent University. Available from: http://www.gbev.org/bioelectricity.htm, visited January 10,2009 .

SANGYOKA S., A. REUNGSANG, S. MOONAMART and R. PHIBOONSONGKRAM. 2007. Repeated-batch fermentative for bio-hydrogen production from cassava starch manufacturing wastewater. Available from: www.ansijournals.com/pjbs/ 2007/1782-1789.pdf, visited November 27, 2008.

SAS. 1985. SAS User's Guide. Statistical Version. 5th Ed. SAS Institute, Inc. Cary, NC.

THAUER R.K., K. JUNGERMANN and K. DECKER. 1977. Energy conservation from chemoptrophic anaerobic bacteria. Available from: http://www.pubmedcenta.nih. gov/ pagerender.fcgi?artid=413997\&pageindex=9\# page, visited February 12, 2009. 